\title{
Electronics Student Worksheet Based on Higher Order Thinking Skills for Grade IV Elementary School
}

\section{Sri Rahayu1*, Iskandar Ladamay², Bambang Budi Wiyono ${ }^{3}$, Romia Hari Susanti ${ }^{4}$, Naufal Rafif Purwito 5}

\author{
1,2,4,5 Universitas PGRI Kanjuruhan Malang, Malang, Indonesia \\ ${ }^{3}$ Administrasi Pendidikan/Manajemen Pendidikan, Universitas Negeri Malang, Malang, Indonesia
}

\section{ART I CLE I N F O}

Article history:

Received June 02, 2021

Revised June 03, 2021

Accepted July 27, 2021

Available online August 25, 2021

Kata Kunci:

Lembar Kerja Peserta Didik,

HOTS

Keywords:

The Student Worksheets, HOTS

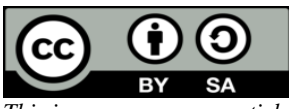

This is an open access article under the CC BY-SA license.

Copyright (C) 2021 by Author.

Published by Universitas Pendidikan Ganesha.

\begin{abstract}
A B S T R A K
Lembar Kerja Peserta Didik (LKPD) yang tersedia selama ini hanya berisikan tulisan hitam putih. Selain itu, gambar dan soal-soal yang disajikan tidak menarik minat belajar siswa. Oleh sebab itu, perlu dikembangkan LKPD yang dapat menarik minat belajar siswa. Tujuan penelitian ini adalah untuk mengembangkan Elektronik LKPD (E-LKPD) pembalajaran tematik berbasis High Order Thinking Skill (HOTS). Penelitian ini merupakan jenis penelitian pengembangan (RnD). Model pengembangan menggunakan model ADDIE yang terdiri atas tahap Analysis, Design, Development, Implementation, dan Evaluation. Produk E-LKPD yang telah dikembangkan kemudian diujicobakan kepada validator, guru, dan siswa untuk mengetahui keefektifan penggunaannya. Teknik analisis data dilakukan secara deskriptif kualitatif dan kuantitatif. Validasi dilakukan oleh tiga validator yaitu validator konten, materi, dan bahasa. Instrumen penelitian yaitu angket respon guru untuk kepratisan dan angket respon siswa untuk kemenarikan. Rata-rata hasil validasi ahli media adalah 3,6 dengan kategori "sangat valid", ahli materi adalah 3,83 dengan kategori "sangat valid", dan ahli bahasa adalah 2,83 kategori "valid" dengan revisi. Hasil analisis kepraktisan E-LKPD dapat dinilai dari hasil skor angket guru diperoleh skor 3,43 dengan kategori "sangat praktis" sedangkan hasil analisis kemenarikan E-LKPD diperoleh dari hasil skor angket siswa dengan skor 3,19 dengan kategori "baik". Berdasarkan uji coba diperoleh simpulan bahwa hasil pengembangan produk E-LKPD pembalajaran tematik berbasis HOTS valid, praktis, dan menarik digunakan dalam pembelajaran di kelas IV Sekolah Dasar.
\end{abstract}

A B S T R A C T

The Student Worksheets (LKPD) available so far only contain black and white writing. In addition, the pictures and questions presented did not attract students' interest in learning. Therefore, it is necessary to develop LKPD that can attract students' learning interests. This study aims to develop Electronic LKPD (E-LKPD) thematic learning based on Higher Order Thinking Skills (HOTS). This research is a type of development research (RnD). The development model uses the ADDIE model which consists of the Analysis, Design, Development, Implementation, Evaluation stages. The ELKPD product that has been developed is then tested on validators, teachers, and students to determine the effectiveness of its use. Data analysis techniques were carried out descriptively, qualitatively, and quantitatively. Validation is carried out by three validators, namely content, material, and language validators. The research instrument is a teacher response questionnaire for practicality and a student response questionnaire for attractiveness. The average validation result of media experts is 3.6 with the "very valid" category, while the material expert is 3.83 with the "very valid" category and the linguist is 2.83 in the "valid" category with revisions. The results of the analysis of the practicality of the E-LKPD can be assessed from the results of the teacher's questionnaire score obtained a score of 3.43 in the "very practical" category while the results of the analysis of the attractiveness of the ELKPD obtained from the results of the student questionnaire score with a score of 3.19 in the "good" category. Based on the trial, it was concluded that the results of developing the E-LKPD product for HOTS-based thematic learning were valid, practical, and interesting to use in learning in grade IV elementary schools.

\section{INTRODUCTION}

LKPD (student worksheet) is an instructional tool that consist a series of questions and information designed to guide students in understanding complex ideas (Choo et al., 2011). LKPD as one of the teaching materials have important role in providing assignments relevant to the material being taught to students, learning will be easier if accompanied by learning resources like LKPD (Prastowo, 2013). LKPD also useful as supporting facilities in achieving student competencies easily (Ranti \& Usmeldi, 2019). LKPD has a positive role in help students constructing a concept in learning (Yusuf, 2016). LKPD is a learning media that can be used to explore students' abilities in the learning process (Latifah et 
al., 2016). Moreover, in implementing the 2013 Curriculum which developed using thematic approach, school must be able to package the learning materials in the form of LKPD. But the problem are, LKPD used so far only contains questions that less interesting students to learn, the LKPD used contains only black and white writing and not many picture to increase student interest (Koderi et al., 2019). Based on the results of observation in schools by researchers, known that the utilization of LKPD take on several obstacles such as not qualify the characteristics of students and not being able to motivate students in the learning process. This is because the LKPD used is less attractive, less effective and considered not optimal causes students to be less motivated to use the available LKPD.

The results of interview between researchers with teacher during the preliminary study stated that, the LKPD used so far is not able to improve students' high level thinking skills or still facilitates students' low level thinking (Low Order Thinking Skills). This statement supported by the research result, state that $85 \%$ of the material in the LKPD still reach LOTS level (thinking levels C1-C3), this statement meaning that the levels of thinking C4, C5, and C6 (HOTS) are still 15\% (Ladamay et al., 2021). Even though LKPD is needed by students to improve their learning outcomes (Jowita, 2017). LKPD is very important as a supporting facilities to supporting students in achieving their competencies and helping students construct material concepts (Ranti \& Usmeldi, 2019; Yusuf, 2016). So that the development of LKPD teaching materials are able to improve students' High Order Thinking Skills (HOTS) is very necessary. LKPD teaching materials developed by teachers must be in accordance with the guidelines of 2013 Curriculum that is, can improve students' ability to think at high levels of HOTS. High Order Thinking Skills is an ability that must exist in every student (Darmawan \& Wahyudin, 2018). Teachers need to have creativity in developing teaching materials (Wandari et al., 2018). Teaching materials was developed by teachers must be able to improve students' higher order thinking skills (HOTS) (Hartik et al., 2021).

In addition, the development of LKPD teaching materials during the Pandemic Covid 19 is very much needed. On the Pandemic Covid 19 the leaning process that usually done conventionally has turned into distance learning or online (Sadikin \& Hamidah, 2020). So that the use of conventional LKPD must be changed to Electronic LKPD so it can be used by students, especially during the Pandemic. The development of learning media based on technology of communication has a very high effect on students achievement (Ratheeswari, 2018). The use of electronic media as a tool in the learning process can affect the quality of student learning (Lestari, 2018). Learning media in the form of Electronic LKPD is intended to optimize teaching and learning activities (Yasa et al., 2018). But unfortunately there are still many teachers who have not used technology in the learning process (Fadila et al., 2019). Finding students ability to think at higher level (HOTS) is still low, and the availability of conventional LKPD is still not optimal for use in the distance learning as it is today, it is necessary to use Electronic LKPD based on High Order Thinking Skills (HOTS). Thus, this study aims to develop the Electronic LKPD based on High Order Thinking Skills (HOTS) for Grade IV Elementary School Students Theme 8 Subtheme 3 Learning 2.

\section{METHOD}

This research type is Research \& Development (R\&D) that uses the ADDIE (Analysis, Design, Development, Implementation and Evaluation) model (Sukaesih et al., 2019). The goal is to produce new product or to develop existing products for the learning process in school and to test the effectiveness of the product that was developed. The stages of the ADDIE development model are as follows on Figure 1. The ADDIE model is the perfect model from the early analysis stage problems, designing a learning media, media experts and material experts validate learning media to analyze whether of not a media design is feasible to implement. Every stage of the ADDIE model is always carried out evaluation to improve learning media (Wijaya et al., 2020).

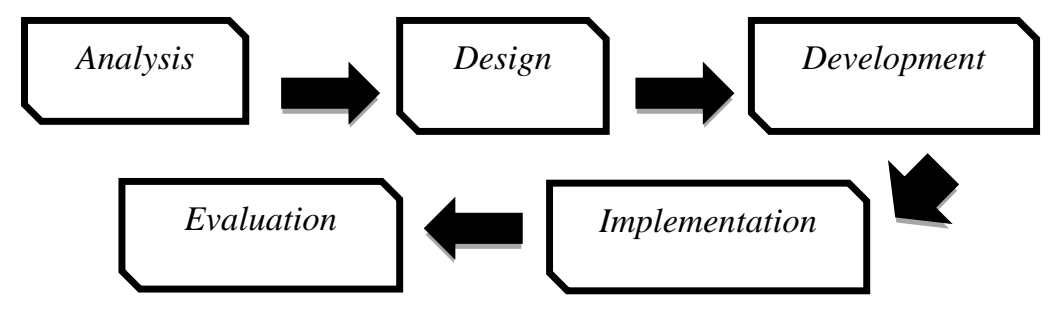

Figure 1. Model ADDIE 
The subjects of this research is students of grade IV which in even semester at MI Nurul Islam Krai who selected randomly. Before the product implemented, the product is tested on validators to obtain improvements in order to achieve the level of validity, practicality and effectiveness of the E-LKPD products that have been developed. The instrument grid and instrument validity criteria can be seen in Table bellow. Data analysis techniques were carried out quantitatively and qualitatively.

Table 1. Aspects of Assessment by Material Expert Validators

\begin{tabular}{lc}
\hline No & Rating Indicator \\
\hline \multicolumn{2}{c}{ Content Eligibility } \\
\hline 1. & Presentation Techniques \\
2. & Presentation Support \\
3. & Learning Presentation \\
4. & Completeness of Presentation \\
\hline \multicolumn{2}{c}{ Material Eligibility } \\
\hline 6. & Compatibility of Material with KD Developed \\
7. & Material Accuracy \\
\hline 8. & Material Update \\
\hline
\end{tabular}

Table 2. Aspects of Assessment by Media Expert Validators

\begin{tabular}{lc}
\hline No & Rating Indicator \\
\hline 1. & Language \\
2. & Presentation \\
3. & Effects of Media on Learning Strategies \\
4. & Full View \\
\hline
\end{tabular}

Table 3. Aspects of Assessment by Linguist Validators

\begin{tabular}{lc}
\hline No & Rating Indicator \\
\hline 1. & Presentation \\
2. & Language Ease \\
3. & Language Standards \\
\hline
\end{tabular}

Table 4. Final Assessment Criteria

\begin{tabular}{cc}
\hline Achievement Precentage & Interpretation \\
\hline $3,26-4,00$ & Very Valid \\
$2,51-3,25$ & Valid \\
$1,76-2,50$ & Less Valid \\
$1,01-1,75$ & Not Valid \\
\hline
\end{tabular}

Based on the research model that has been described, the researcher adapts the development model from the following ADDIE model stages. Analysis, the analysis stage is the initial stage in the ADDIE development model. This stage consists of needs analysis, curriculum analysis, and analysis of student characteristics. At this stage, what needs to be identified regarding student needs is educational learning that can help students play an active role. In this development, appropriate and appropriate references are needed with the level of student understanding. This can be done by observing class IV at MI Nurul Islam Krai. At the characteristic analysis stage, the thing that needs to be analyzed is about the level of development of the fourth grade students of MI Nurul Islam Krai who will be the subject of research in using learning media developed by researchers. Characteristic analysis is done by observing the fourth grade students directly in the learning process.

At design stage, the researcher makes a media concept design that will be made. Apart from making media designs, researchers are also media research instruments. The research instrument used to measure product performance is a teacher's questionnaire to measure the practicality of the media, a student response questionnaire to see the attractiveness of students regarding the media. Development is the process of making a design a reality. One important step in the development stage is testing before 
implementation. Media that has been developed and declared worthy of testing by the validator. Furthermore, it was tested on students at MI Nurul Islam Krai. Students were given a response questionnaire to determine the attractiveness of the media that had been developed. The trial was conducted with a small group trial. The results of the questionnaire will be analyzed and evaluated which can further determine the quality, value of benefits, and student responses to the product. The results of the analysis, evaluation and student responses are used to determine the attractiveness of the media. The types of data used in this research are quantitative and qualitative data. Quantitative data in this development research were obtained from student response questionnaires as a feasibility test. The qualitative data in this study was obtained from the validator's response. The questionnaire was assessed using a Likert scale questionnaire with four categories of assessment, namely strongly agree, agree, disagree and strongly disagree. The instruments used in this study were three instruments, namely the results of validity, results of media feasibility and results of media attractiveness.

\section{RESULT AND DISCUSSION}

\section{Result}

This preliminary research was done by observing the school and at the same time interviewed the teachers. The purpose of this preliminary research was to obtain initial data of preliminary analysis. Interviews were conducted to the teachers to determine the curriculum used at the school. The needs analysis of class IV at MI Nurul Islam Krai are that teachers still find it difficult to implement teaching and learning activities that are in accordance with the 2013 Curriculum which learning activities are centered on students, but in practice it is difficult to do. Several factors affect the difficulty of implementing the 2013 Curriculum, is that LKPD teaching materials are published by the government, the contents of LKPD are not in accordance with the characteristics of students and the physical appearance of LKPD is very simple. So it is necessary to develop teaching materials in the form of E-LKPD that are in accordance with the characteristics of students so that students are more active in learning.

The product was developed in this research is E-LKPD (Electronic Student Worksheet) based on Higher Order Thinking Skill (HOTS) in which there is material for class 4 Theme 8 Subtheme 3 Lesson 2. The results of the KD analysis in this curriculum are 1) Indonesian: Observing the characters in the fictional text, 2) IPA: Related force to motion to events in the sorrounding environment, 3) SBdP: Knowing three dimensional drawings and shapes. The design of the E-LKPD content is made on the frame material form according to what has been regulated in the Curriculum SK-KD. The design of the E-LKPD display manifests itself in diagrams/flow charts and storyboards. This E-LKPD use software Kvisoft Flip Book Maker. Kvisoft Flip Book Maker is more interesting like conventional book in digital form. This software is proven to be a good and suitable virtual flipbook, the operating system is uncomplicated and attractive for student (Rasiman. \& Pramasdyahsari, 2014).

E-LKPD Thematic Learning Based on High Order Thinking Skill (HOTS) was successfully developed the next stage is tested for validation by 3 validators that are Material Expert, Linguistic Expert, and Media Expert. The assessment result from 3 validators mentioned can be seen bellow. The result of Material Expert Assessment there are 1) Aspect of content eligibility get score 4 with criteria very valid, 2) aspect of material eligibility get score 3.5 with criteria very valid, 3) aspect language eligibility get score 4 with criteria very valid. So total for material expert assessment results is 11.5 while the average is 3.83 with criteria very valid. As for comments and suggestions for improvement from the material expert validator is the material needs to be clarified, especially indicators about getting to know the characters in the story, please correct them according to suggestion from validator material expert.

The result of Linguistic Expert Assessment Results there are 1) Aspect of presentation get score 3.33 with criteria very valid, 2) aspect of easy language get score 2.4 with enough valid, 3) aspect of language standards get score 2.75 with score valid. So total for linguistic expert assement results is 8.48 while the average is 2.83 with criteria valid. As for comments and suggenstions for improvement from linguistic expert validator is put the Unikama logo and the authors name on the cover, the writing on the E-LKPD should be enlarged, on each video write down the source of the video obtained. The result of Media Expert Assessment Results there are 1) Aspect of language get score 3.3 with criteria very valid, 2) aspect of presentation get score 4 with criteria very valid, 3) aspect of media affects o learning strategies get score 3.5 with criteria very valid, 4) aspect of alternate view get score 3.6 with criteria very valid. So total for media expert assement results is 14.4 while the average is 3.6 with criteria very valid. As for comments and suggenstions for improvement from media expert validator is please really fill in the ELKPD according to the theme, don't contain cartoons but there is no essence of benefits for children, increase the number of practice questions because that is highlighted is electronic student worksheets, for example activity units 1 to 6 and also provides an assessment rubric in each unit, the language used in the 
E-LKPD is not illustrative according to the characteristics of 4th grade elementary school students, please use the language of instruction in the contents of the E-LKPD in the electronic special instructions section, it has not been emphasized that the contents of the E-LKPD are only general instructions.

After being declared eligible by the validators, the E-LKPD is applied to small groups. And then the product of E-LKPD must be evaluated. At this stage the assessment that is seen is the practicality aspect and the attractiveness aspect of the E-LKPD. The practical aspect can be seen from the teacher's response questionnaire, while the attractiveness aspect can be seen from the results of the student response questionnaire with the following results. The result of Teacher Responses Questionnaire there are 1) Aspect of language is 3.3 with criteria very practical, 2) aspect of presentation is 3.5 with criteria very practical, 3) aspect of condition is 3.5 with criteria very practical. So total for teacher responses questionnaire results data is 10.3 while the average is 3.43 with criteria very practical. As for comments and suggenstions for improvement from teacher is the color needs to be fixed to make it attractive. While the results of analysis the attractiveness E-LKPD obtained from results of student questionnaire score 3.19 with "good" category.

\section{Discussion}

Based on the results of the research on the development of Electronic LKPD Thematic Learning based on High Order Thinking Skills (HOTS) above, the product that have been developed is very effective to be applied. This is absolute based on assessments from material expert, media expert, linguist expert, practicality test on teachers and attractiveness test on students. These results can be understood and mean that the Electronic LKPD Thematic Learning based on HOTS for Grade IV elementary school is very useful in helping students understand more concrete, helping students construct materials, and can facilitate students' ability to think at higher level C4 (analyzing), C5 (evaluating), C6 (creating). Electronic LKPD Thematic Learning based on HOTS makes students no feel bored while learning process because learning and doing practice questions becomes more fun.

The different this research from similar research is the development of Electronic LKPD is the use of HOTS questions in the E-LKPD. The HOTS elements designed for each item on the Electronic LKPD are able to make students discover new knowledge gained and achieve possible answers in new situation (Kusuma et al., 2017). Developing Electronic LKPD based on HOTS will make students analyze and interpret previous information so that it is not monotonous. In addition, the HOTS questions presented in the Electronic LKPD are not just memorization questions but can improve the quality of questions and assessment results. The goal is that students are not only required to memorize but also be able to apply it in everyday life such as to solve certain problems.

HOTS questions are not difficult, the editorials are long and convoluted so that they do not waste the readers time and are systematic to measure Competency Achievement Indicators (IKK) effectively and have material depth of material so that students will be stimulated to answer questions well. The characteristics of HOTS questions include measuring HOTS based on contextual problems in various forms of question items (Widiana, 2017). Future generations need HOTS thinking skills to take on with complex situations, so that everyone is able to solve these problems, think critically, have creativity and be able to collaborate to find solutions to the problems faced. So that teachers really need to train High Order Thinking Skills (HOTS) to students (Sunarti et al., 2020).

This E-LKPD is made for thematic learning, because thematic learning is an integrated learning that uses themes to link several subjects so that it can provide meaningful experiences to students. With the link between several subjects, students will gain knowledge and skills as a whole so that learning becomes more meaningful for students. As a process model, thematic learning has characteristics including 1) student-centered, 2) providing direct experience, 3) the separation of subjects is not very clear, 4) presents concepts from various subjects, 5) is flexible, 6) results learning according to the interests and needs of students.

Moreover, in the Pandemic Covid 19 like now, the learning process that is usually done conventionally has turned into distance learning or online (Sadikin \& Hamidah, 2020). The process of distance learning or online learning is very need of information technology (Hanifah Salsabila et al., 2020). Teachers must have classroom management skills by utilizing information and communication technology (Riyadi et al., 2018). Because of this condition, the use of Electronic LKPD is very effectively used by students, especially during the Pademic. The use of Electronic LKPD is one of solution in increasing the mastery of learning materials by students (Choo et al., 2011). Other research also states that Electronic LKPD is more interesting to use in the learning process, can improve student learning outcomes and can train students' critical thinking processes (Haryanto et al., 2020).

The development of technology and communication in learning media has a high influence on student achievement (Ratheeswari, 2018). The use of electronic media as a tool in the learning process 
can affect the quality of student learning (Lestari, 2018). Utilization of information and communication technology in learning can support the development of students' cognitive, affective and social abilities to be higher (Ganefri et al., 2017). The use of technology in the learning process $80 \%$ interesting and easy for students to understand (Ghavifekr \& Rosdy, 2015). The development and selection of modules from printed version modified to an electronic has advantages. Electronic modules make it easier for readers to access digital content, easier distribution and purchase, simple backup and storage, a breakthrough solution for monotonous printed books, providing two way interaction techniques (Fojtik, 2015; Jou et al., 2016).

Electronic LKPD as student exercise sheets that are made digitally and carried out systematically and continuously for a certain period of time (Rai et al., 2021). E-Book is a form of technology has effective and relevant content and features (Panyajamorn et al., 2018). Practical methods and innovative techniques for understanding information that link textual knowledge and technology help readers to be active in the learning environment (Mohan \& Kesari, 2016). This Electronik LKPD using Kvisoft Flipbook Maker application. Kvisoft Flipbook Maker is an interactive multimedia software to create teaching materials from Portable Document Format (PDF) into flash pages, each PDF page is made like a real book sheet by flipping through each page so that it can resemble an online magazine, e-newspaper, and digital books (Putri et al., 2020). The content is all types of audio of visual material including speech, text, music, animation, photos, of video and any different combinations (Embong et al., 2012). According to Rasiman \& Anggita Kvisoft, it is proven that virtual flipbooks are good and suitable to be used for teaching materials so that learning materials become easy to understand, interesting and effective for students to have critical thinking skills. Because there are elements of animation and there is also music which is considered very good for students in the learning and learning process (Rasiman. \& Pramasdyahsari, 2014).

Therefore, the Electronic LKPD Thematic Learning based on HOTS can be a very effective learning media used in the learning process, especially during Pandemic Covid 19 like now. In addition, HOTS elements was presented in the Electronic LKPD are the difference between this research and other research. HOTS questions are able to make students discover new knowledge, analyze and interpret information. Students are not only required to memorize but also be able to apply it in everyday life such as to solve problems. This product can be used by teachers in elementary schools as an additional reference for teaching, adding insight to teachers to be able to develop teaching materials that can improve higher order and critical thinking skills, interests, learning outcomes and explore the types of intelligence possessed by students.

\section{CONCLUSION}

This development research resulted a teaching material product in the form of Electronic Student Worksheets (E-LKPD) thematic learning based on Higher Order Thinking Skill (HOTS) for grade 4 theme 8 Sub-theme 3 Learning 2. This product give better understand to students because the question based on High Order Thinking Skill (HOTS) are applied in all subject matter in the thematic learning on ELKPD. So students not feel bored during learning process, more than that students are used to doing High Order Thinking processes.

\section{REFERENCES}

Choo, S. S. Y., Rotgans, J. I., Yew, E. H. J., \& Schmidt, H. G. (2011). Effect of Worksheet Scaffolds on Student Learning in Problem-Based Learning. Advances in Health Sciences Education, 16(4), 517-528. https://doi.org/10.1007/s10459-011-9288-1.

Darmawan, D., \& Wahyudin, D. (2018). Model Pembelajaran di Sekolah. PT Remaja Rosdakarya.

Embong, A. M., Noor, A. M., Hashim, H. M., Ali, R. M., \& Shaari, Z. H. (2012). E-Books as Textbooks in the Classroom. Procedia - Social and Behavioral Sciences, 47, 1802-1809. https://doi.org/10.1016/j.sbspro.2012.06.903.

Fadila, A., Dasari, R., Setiyaningsih, S., Septiana, R., Sari, R. M., \& Rosyid, A. (2019). The Development of Electronic Flash Worksheet Based on Adobe Flash Cs6 on Fraction Numbers in the Seventh Grade of Junior High School. Journal of Physics: Conference Series, 1155(1), 1-7. https://doi.org/10.1088/1742-6596/1155/1/012019.

Fojtik, R. (2015). Ebooks and Mobile Devices in Education. Procedia - Social and Behavioral Sciences, 182, 742-745. https://doi.org/10.1016/j.sbspro.2015.04.824.

Ganefri, Hidayat, H., Kusumaningrum, I., \& Mardin, A. (2017). Needs Analysis of Entrepreneurships Pedagogy of Technology and Vocational Education with Production Based Learning Approach in 
Higher Education. International Journal on Advanced Science, Engineering and Information Technology, 7(5), 1701-1707. https://doi.org/10.18517/ijaseit.7.5.1510.

Ghavifekr, S., \& Rosdy, W. A. W. (2015). Teaching and Learning with Technology: Effectiveness of ICT integration in Schools. International Journal of Research in Education and Science, 1(2), 175-191. https: //doi.org/10.21890/ijres.23596.

Hanifah Salsabila, U., Irna Sari, L., Haibati Lathif, K., Puji Lestari, A., \& Ayuning, A. (2020). Peran Teknologi dalam Pembelajaran di Masa Pandemi Covid-19. Al-Mutharahah: Jurnal Penelitian dan Kajian Sosial Keagamaan, 17(2), 188-198. https://doi.org/10.46781/al-mutharahah.v17i2.138.

Hartik, S., Utaminingsih, S., \& Madjdi, A. H. (2021). A Need Assessment of Integrated Science Teaching Material Based Higher Order Thinking Skills (HOTS). Journal of Physics: Conference Series, 1823(1), 1-7. https://doi.org/10.1088/1742-6596/1823/1/012078.

Haryanto, Asrial, \& Ernawati, M. D. W. (2020). E-Worksheet for Science Processing Skills Using Kvisoft Flipbook. International Journal of Online and Biomedical Engineering, 16(3), 46-58. https://doi.org/10.3991/IJOE.V16I03.12381.

Jou, M., Tennyson, R. D., Wang, J., \& Huang, S.-Y. (2016). A Study on the Usability of E-Books and APP in Engineering Cources: A Case Study on Mechanical Drawing. Computer Education, 92, 181-193. https://doi.org/10.1016/j.compedu.2015.10.004.

Koderi, K., Latifah, S., Fakhri, J., Fauzan, A., \& Sari, Y. P. (2019). Developing Electronic Student Worksheet Using 3D Professional Pageflip Based on Scientific Literacy on Sound Wave Material. Journal of Physics: Conference Series, 1467(1), 1-9. https://doi.org/10.1088/1742-6596/1467/1/012043.

Kusuma, M. D., Rosidin, U., Abdurrahman, A., \& Suyatna, A. (2017). The Development of Higher Order Thinking Skill (HOTS) Instrument Assessment in Physics Study. IOSR Journal of Research \& Method in Education (IOSRJRME), 07(01), 26-32. https://doi.org/10.9790/7388-0701052632.

Ladamay, I., Kumala, F. N., Susanti, R. H., Ulfatin, N., Wiyono, B. B., \& Rahayu, S. (2021). Designing and Analysing Electronic Student Worksheet Based on Kvisoft Flip Book Maker for Elementary School Student. The 5th Annual Applied Science and Engineering Conference (AASEC 2020), 1098. https://doi.org/10.1088/1757-899X/1098/3/032028.

Latifah, S., Setiawati, E., \& Basith, A. (2016). Pengembangan Lembar Kerja Peserta Didik (LKPD) Berorientasi Nilai-Nilai Agama Islam melalui Pendekatan Inkuiri Terbimbing pada Materi Suhu dan Kalor. Jurnal Ilmiah Pendidikan Fisika Al-Biruni, 5(1), 43-51. https://doi.org/10.24042/jpifalbiruni.v5i1.104.

Lestari, S. (2018). Peran Teknologi dalam Pendidikan di Era Globalisasi. Edureligia; Jurnal Pendidikan Agama Islam, 2(2), 94-100. https://doi.org/10.33650/edureligia.v2i2.459.

Panyajamorn, T., Suanmali, S., Kohda, Y., Chongphaisal, P., \& Supnithi, T. (2018). Effectiveness of ELearning Design in Thai Public Schools. Malaysian Journal of Learning and Instruction, 15(1), 1-34. https://doi.org/10.32890/mjli2018.15.1.1.

Prastowo, A. (2013). Pengembangan Bahan Ajar Tematik. Diva Press.

Putri, R. A., Uchtiawati, S., Fauziah, N., \& Huda, S. (2020). Development of Interactive Learning Media Flip Book Using Kvisoft Flip Book Maker Based on Local Culture Arts. Innovation Research Journal, 1(1), 55-64. http://dx.doi.org/10.30587/innovation.v1i1.1442.

Rai, I. M., Wiranata, A., \& Sujana, I. W. (2021). Pengembangan Lembar Kerja Peserta Didik Berbasis Pemecahan Masalah Kontekstual Materi Masalah Sosial Kelas IV SD. Jurnal Pedagogi Dan Pembelajaran, 4(1), 30-38. http://dx.doi.org/10.23887/jp2.v4i1.31926.

Ranti, S., \& Usmeldi. (2019). Development of Integrated Science Student's Worksheet (LKPD) Based on Research-Based Learning Integrated With Religion Value. Journal of Physics: Conference Series, 1185(1), 1-10. https://doi.org/10.1088/1742-6596/1185/1/012143.

Rasiman., \& Pramasdyahsari, A. S. (2014). Development of Mathematics Learning Media E-Comic Based on Flip Book Maker to Increase the Critical Thinking Skill and Character of Junior High School Students. International Journal of Education and Research, 2(11), 535-544. http://eprints.upgris.ac.id/349/.

Ratheeswari, K. (2018). Information Communication Technology in Education. Journal of Applied and Advanced Research, 3(1), 45-47. https://doi.org/10.21839/jaar.2018.v3is1.169.

Riyadi, B., Ertikanto, C., \& Suyatna, A. (2018). The Analysis and Design of Guided Inquiry E-Worskheet Based to Develop High Order Thinking Skills. International Journal Research - Granthaalayah, 6(7), 223-233. https://doi.org/10.5281/zenodo.1336682.

Sadikin, A., \& Hamidah, A. (2020). Pembelajaran Daring di Tengah Wabah Covid-19. Biodik, 6(2), $109-119$. https: //doi.org/10.22437/bio.v6i2.9759.

Sukaesih, S., Ridlo, S., \& Saptono, S. (2019). Development of Biology Teaching Management Textbooks Based on Competency and Conservation to Maximize Pedagogical and Content Knowledge (PCK) 
the Prospective Teachers. Journal of Physics: Conference Series, 1321(3), 1-7. https: //doi.org/10.1088/1742-6596/1321/3/032114.

Sunarti, T., Wasis, Supardiyono, \& Jauhariyah, M. (2020). Train the Skills of Making HOTS Based Physic Questions to Physics Teachers in Mojokerto. Journal of Physics: Conference Series Series, 1805, 112. https://doi.org/10.1088/1742-6596/1805/1/012027.

Syaifuddin, M. (2017). Implementasi Pembelajaran Tematik di Kelas 2 SD Negeri Demangan Yogyakarta. Tadris: Jurnal Keguruan dan Ilmu Tarbiyah, 2(2), 139. https://doi.org/10.24042/tadris.v2i2.2142.

Wandari, A., Kamid, K., \& Maison, M. (2018). Pengembangan Lembar Kerja Peserta Didik (LKPD) pada Materi Geometri berbasis Budaya Jambi untuk Meningkatkan Kreativitas Siswa. Edumatika: Jurnal Riset Pendidikan Matematika, 1(2), 47-55. https://doi.org/10.32939/ejrpm.v1i2.232.

Widiana, I. W. (2017). Higher Order Thinking Skills Assesment (HOTS). Journal of Indonesian Student Assessment and Evaluation, 3(1), 32-44. https://core.ac.uk/download/pdf/226298448.pdf.

Wijaya, T. T., Murni, S., Purnama, A., \& Tanuwijaya, H. (2020). Pengembangan Media Pembelajaran Berbasis TPACK Menggunakan Hawgent Dynamic Mathematics Software. COLLASE (Creative of $\begin{array}{llll}\text { Learning Students } & \text { Elementary }\end{array}$ https://journal.ikipsiliwangi.ac.id/index.php/collase/article/view/4088.

Yasa, A. D., Chrisyarani, D. D., Akbar, S., \& Mudiono, A. (2018). E-Module Based on Ncesoft Flip Book Maker for Primary School Students. International Journal of Engineering and Technology(UAE), 7(3), 286-289.

Yusuf, A. M. (2016). Implementation of Worksheet Based on Productive Questions to Improve Inquiry Skill of Senior High School Students. Proceedings of ICMSTEA 2016: International Conference on Mathematics, Science, Technology, Education, and Their Applications, October, 444-450. https://ojs.unm.ac.id/icmstea/article/view/2716. 